\title{
Possibilities for the Improvement of the Access to MEP Systems in Apartment Buildings
}

\author{
Tatjana JURENIĆ, Miloš GAŠIĆ, Aleksandra ČABARKAPA
}

\begin{abstract}
This paper offers the possibilities for providing easier access to MEP systems in multi-storey apartment buildings from mass post-war developments, common for ex socialist countries. Insufficiently defined ownership relations and legal regulations in this area are the cause for inadequate access to and maintenance of MEP systems. The aim of the research was to indicate the need for establishing new technical and technological conditions and laws on building and maintenance of MEP in mixed ownership apartment buildings both in new market and in social conditions. The research included the analysis of buildings belonging to typical apartment blocks. Measures and recommendations for the improvement in the design stage as well as interventions in existing buildings and regulations are presented as the research outcome.
\end{abstract}

Key words: access; apartment buildings; improvement; MEP system; regulations

\section{INTRODUCTION}

Apartment buildings maintenance is an ongoing process throughout the entire building life cycle consisting of activities that are well designed, timely implemented, technically and economically justified and efficient. It is important to reduce or prevent damage to the building elements through maintenance [1], thus preserving the value of the housing stock and the quality of the building [2]. Effective maintenance of the building performance can minimize the adverse effects of buildings on the environment in terms of energy consumption, carbon dioxide emissions, and waste generation. [3]

After the Second World War in former Yugoslavia, apartment buildings, as well as apartment units, were mostly of social ownership, and only a small percentage was privately owned. Consequently, the building technology and attitude toward these buildings was derived from the economic possibilities and needs of society, in time of rapid expansion of cities. At that time, ownership of common spaces and MEP systems in apartment buildings was not an issue, because it was also under social ownership. The apartments were granted to future beneficiaries - occupancy right holders, who had no sense of protection and maintenance towards them, and even less towards the building that was a joint property. Considering the large investment costs of installations and devices in buildings, the problem of the MEP systems was solved by considering the apartment building as the basic unit, not a single apartment. In this way, the investor (the state) significantly reduced the investment costs, and the occupancy right holders secured the maintenance of the MEP systems. [4]

Between 1992 and 1995, by passing a series of laws in the field of housing policy, the largest post-war reform was carried out in the form of massive privatization of the housing stock in Serbia. This changed substantially the property status of most apartments. Generally, privatization has acquired a form of private ownership of an individual apartment or unit in an apartment building and divided rights and obligations related to common elements and parts of the building, which, as extremely important, include MEP systems.

The current situation in Serbia is such that an important issue of resolving obligations towards maintenance of the common parts of the buildings is not precisely defined.
Thus, the attempt to positively change the situation in the field of maintenance, by determining the legal obligation for the owners of apartments to participate in the maintenance costs of the whole building, has failed so far, and in practice the maintenance of apartment buildings has never been worse. Research [5] shows that Serbian respondents expressed a low level of satisfaction related to facilities maintenance precisely due to an undefined regulatory framework in this field.

Considering the fact that the largest percentage of the total housing stock in Serbia, as much as $76.3 \%$ was built during the period of mass post-war development, from 1946 to 1990 , of which over 30\% before 1975 [1], it is clear that, today, the apartment buildings in Serbia are of the average age of about 50 years. A very similar situation is in former SFRY countries for example in Croatia, for the same period $71.25 \%$, with over $54 \%$ before 1980 [7] and Bosnia and Hercegovina [8]. This is a very important indication of a clear need for an intensive approach to the maintenance of the existing housing stock, which is seriously threatened.

In apartment buildings, apart from residential units, there are also common spaces, necessary for the building functioning. Common premises in an apartment building, among others, include spaces for common installations [9]. Since the laws governing this matter use the term common parts of the building (especially when it comes to maintenance obligations), this should refer to a category that is not just a room, but also includes spaces which enable the functionality of the building and are used by all tenants, representing their common indivisible property. Building installations belong to this category. Each of the MEP systems has its own specificities and requirements. Since wastewater is removed from buildings by gravity, the sewage network is especially important, because of its inflexibility and the need to enable rapid and unobstructed evacuation of wastewater from sanitary facilities.

Plumbing and sewerage networks, although completely different in terms of characteristics and mode of operation, represent an inseparable system. Water and sewage installations, apart from their specificities, are treated in this paper both as part of the building and as MEP systems, whose design and calculations are done by architects. Proper design of installations in buildings is the best strategy for ensuring their energy and ecological efficiency. [10] The key point in the design of MEP 
systems in apartment buildings are the sanitary facilities (bathrooms and toilets) and kitchens due to the number of different installations necessary for proper functioning of these spaces.

This paper analyzes the possibilities for providing easier access to MEP systems in multi-storey apartment buildings, as well as the constraints that exist in this process. Insufficiently defined ownership relations and legal regulations in this area make it difficult to access and maintain MEP systems, and therefore their smooth functioning. Equally relevant is the design of space where the importance of these areas should be recognized. The research includes the analysis of developed housing settlements in Belgrade: Banjica with over 4,500 apartments, Blocks 61 and 62 in New Belgrade with around 1400, Julino Brdo with over 1,000 apartments and 3 tower apartment buildings in Novi Sad with over 200 apartments [11].

The aim of this paper is to propose possible solutions from the angle of the architectural profession in order to contribute to the theoretical basis and defining legal regulations regarding installations and their maintenance in apartment buildings.

\section{WATER SUPPLY AND SEWERAGE NETWORK IN REGULATIONS}

The sewerage network is, according to the position in the building, divided into the upper verticals, the horizontal branches along the floors and the lower horizontal distribution. From the aspect of maintenance it is very important to access the network and determine the right of jurisdiction for parts of the installation network. This practically means the following: horizontal branches spatially belong to the apartment in which they are, so it is logical to provide access to the network within the apartment without compromising neighbouring apartments. This is important in case of emergency interventions, as well as reconstructions within the apartment. Verticals belong to the common parts of the building and as such should be accessible from common property spaces (communication spaces, common storage, etc.) and rooms designed for this purpose. This should be clearly and precisely determined through regulations and technical conditions. Present practice is recommending that the network ducts for sanitary and atmospheric water outside and inside of the building be set up so that it is relatively easily accessible for control and maintenance, as well as for intervention in case of repair [12] leaving too much opportunity for free interpretation of regulations, and therefore an undefined jurisdiction over MEP systems.

A review of the technical regulations [13] and technical conditions for the sewage system [12] shows that very little attention is paid to the regulations regarding piping, and the position of the network in relation to individual premises and access to the revision openings. In addition, there are no regulations for building reconstructions in cases when floors are added, that would deal with the way of connecting new MEP system and sanitary facilities with the existing ones, without compromising the existing flats.

Water plumbing installations are much easier for operation and maintenance than sewer installations, since water flow is provided by pressure and not by gravity, due to which the diameter of water pipes in apartment buildings is relatively small. This allows flexibility in setting up pipes in minimal spaces, which significantly facilitates the access to the plumbing network that supplies a particular apartment. The technical regulations for the water supply network are much more precisely defined than in the case of the sewage network, primarily for the reason of protecting water from contamination. Faults on the water supply network, besides the danger of water quality, can lead to high costs and structural damage if leakage of water under pressure occurs. In this case, location of valves for closing the water supply with or without discharge is extremely important until the fault is repaired. The position of the water meter, as well as its protection, is of exceptional importance, which is clearly prescribed, [13]. In practice so far, the decision to install individual water meters per apartment was made individually on a case-bycase basis, [12]. However, considering the possibility of placing individual water meters in apartments becomes a practice for newly constructed buildings, which will allow tenants to control the water consumption for each apartment separately. This is already applied in multistorey buildings which contain business premises on the ground floor, where different water consumption, as well as the conditions for payment, are regulated by placing different water meters for housing and office space [12]. It is also prescribed to install a distributor which would allow each vertical water pipe to be closed individually in the event of a malfunction [12], but it would be necessary to clearly define the location of the distributor within the common spaces.

Based on the review of the relevant regulations, it can be concluded that the technical regulations and conditions for the water supply network are largely defined, since in practice the city water and sewage company prescribes measures, conditions, controls and performs repairs, but in order to better control the water supply and network itself, it would be important to specify the spaces in which measuring devices and valves can be located, as common rooms.

\section{MEP SYSTEMS AND OWNERSHIP RELATIONSHIPS}

Due to the transformation of ownership status already discussed above, the new apartment owners have entered into an obligation to maintain the installation network in the building, even if they do not have any record of the state of the MEP system not only at the time of purchase, but also after several years of use. Even today, more than two decades after the transformation of the apartment ownership in Serbia, and a number of adopted laws, the situation with the physical condition of the existing housing fund is not clear. When analyzing an average apartment building in terms of maintenance, an extremely complex situation can be noticed, due to the fact that there are several owners of different parts of the building, but also regarding a very sensitive issue of access to MEP systems, especially measuring instruments, valves, etc. In order to keep all MEP systems at a satisfactory level, permanent controls and servicing of outworn parts of all types of installations are required. The interest of each owner is that he/she can manage his/her property, i.e., has 
the right to intervene in his/her apartment, without compromising others. This can be accomplished only if ownership obligations are precisely defined, but also if maximum accessibility is provided to the MEP systems. This would, apart from quality maintenance and control, provide the possibility of saving energy and material resources by turning off parts of the network in cases such as a longer absence from the apartment, as well as the possibility of more efficient operation of emergency intervention services in case of need, without extensive construction works and demolitions. Through the analysis of regulations and technical conditions, the sewage network has been identified as specific and significant due to its inflexibility. The existing position of the network in apartment buildings usually allows their separation according to ownership and potential accessibility. The layout can mostly separate shared MEP systems from those belonging to the apartment, thus facilitating both the competence and the obligation of their maintenance to a greater extent, but it does not have to be the rule for all MEP systems. Installation devices are mainly in separate rooms (heating substations, electrical substations, etc.), but besides them, as mentioned above, there are also MEP systems that permeate the whole building and this is met in one of the two common systems:

- disintegrated MEP systems

- integrated MEP systems.

The disintegrated network installation system assumes placement of the vertical lines belonging to various MEP systems in several locations in the facility, as needed, while the integrated system implies that all vertical lines are grouped into a single hub, an installation space, which is most often accessible from a common space, mainly a communication (which is a desirable situation).

Given the property relations and housing policies that refer to the design and construction of most apartment buildings in Serbia, a disintegrated system of installations is mostly encountered. However, the changed ownership, and therefore the obligations of the apartment owners to maintain the MEP systems, require a change of approach during the design process as well as implementation of the integrated system as much as possible.

\section{MEASURES AND RECOMMENDATIONS}

The approach to this problem is multi-layered and complex. Since there is a significantly larger number of existing buildings different in condition and structure, it is impossible to determine only one direction of action. For new, future buildings, the situation is relatively simple, because through specific recommendations for designing and synchronized cooperation of the participants in the project, good solutions can be obtained that meet the requirements in terms of architecture and functioning of the installations. In existing buildings it is much more complicated because in many cases it requires subsequent solutions, often smaller structure interventions, which also entails issues of competence, ownership and material costs. Finally, the most appropriate access to solving this problem, both for existing and new apartment buildings is the legal framework that should cover the entire housing fund.
We can say that there are about three directions or levels which, at certain points, cross and intertwine. One refers to recommendations for the design of future buildings, another to measures and interventions that would be directed towards the existing apartment buildings and improvement of their existing state, and finally a legal framework that would regulate the obligations, rights and responsibilities of all participants.

\subsection{Recommendations for the Design Process}

One of the reliable ways of solving the problem of the inadequate access to MEP systems is acting at the design stage. It is necessary that planners are simultaneously involved and that decision-making is harmonized and coordinated in all stages of the design. In practice, however, it often happens that the design phases are done separately and that the design of installations begins when the architectural part of the project is almost completed.

\subsubsection{The Structural Aspect}

Horizontal branches on floors are most often organized so that the sewage network of the bathroom and toilets is lowered under the ceiling and visible in the apartment/space below the one that uses that part of the network. In the event of any malfunction or need for intervention, it must be carried out in an apartment belonging to another owner. In addition, the installation network on the ceiling of the room, even if it is a bathroom, degrades the space. This is often the only possible solution that is designed and performed because, at the moment of designing the sewer installation, the process of designing is most often completed and the structural elements of the building are dimensioned, positioned and structurally determined. The subsequent attempt to mount the upper horizontal branches above the slab would be impossible without raising the level of the floor only in the sanitary rooms, which is unacceptable from the aspect of functionality and design rules.

A direct interdependence of the design of the upper sewage branches and structural elements of the building is always present. Pipes breaking the structural elements of the building should not endanger the stability of the building, which further complicates the design of an already inflexible sewer network. On the other hand, it is entirely justified to require that the pipes are not visible in the space used. The problem arises when the sewage installation has to meet the stated technical conditions if neither architectural nor structural design provides an opportunity for it. The solution lies in the timely cooperation and coordination of the work of the designer of the building, structural engineer and designer of the MEP system. If designing takes into account the grouping of sanitary spaces, it will be possible to design a quality and functional installation network without compromising the quality of the space or the stability of the building. Fig. 1 shows the design of a typical floor in an apartment building in Belgrade (author Sasic, arch.). Considering the fact that the building is in the residential part of the city, there are high demands regarding the size and layout of the apartment, which spreads throughout the entire floor. Therefore, a number of hygienic facilities are also 
envisaged. By coordinating the work of architects and structural engineers, sanitary installations are grouped between the two supporting elements extending along axes $\mathrm{C}$ and $\mathrm{D}$, so that the intermediate structure is derived between the mentioned axes as an inclined slab. The semiprefabricated ceiling enabled the position of the upper sewer branches above the slab, and the required floor layers were made over the pipes. Waterproofing on the bottom of the slab prevents, in case of leakage, the space on the lower floor to be compromised.

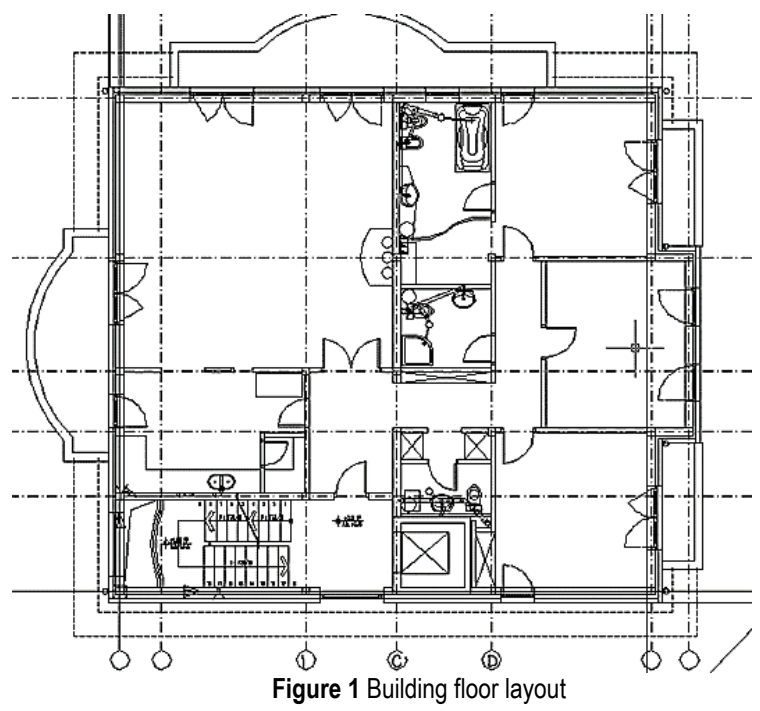

Grouping of sewer installations in the apartment to which it belongs leads to significantly easier maintenance. Also, in this way the pipes are not visible in the apartment below which raises the quality and reduces the investment costs, since there is no need for a suspended ceiling (Fig. 2).

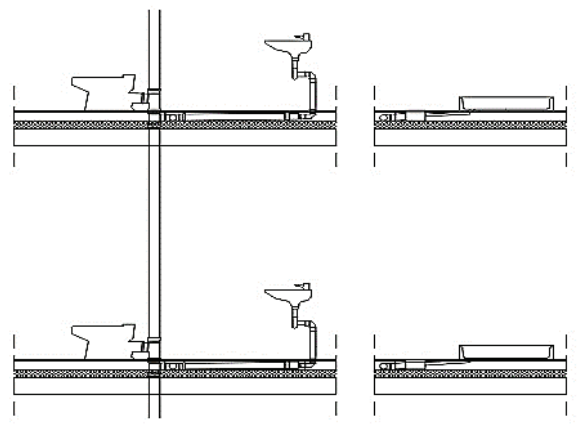

Figure 2 Building drains network section

\subsubsection{The Spatial Organization Aspect}

Position of the sanitary installations. The shorter horizontal branches of the sewage and water supply network are not only the most cost effective, but also functionally significantly better solution. One of the factors that has an impact on this is the layout of sanitary installations, grouped in as few places in the building as possible. A set of sanitary elements connected to MEP systems is commonly referred to as sanitary facilities. The sanitary facility is important for the analysis of MEP systems because it includes several installations, of which the sewage and water supply networks are directly dependent on the arrangement of sanitary elements and sanitary installations in general. There is often a tendency to identify the notion of a sanitary facility with a vertical pipe line. The number of vertical sewage lines significantly affects the layout of the apartment and the cost effectiveness. Grouping and connecting sanitary facilities considerably contributes to the lower cost of a building. One of the presumptions for easier access to installations is to group installations into installation blocks or walls to form, preferably, a system of integrated MEP systems. This is especially important for large apartment buildings and complexes, when designing should take into account the possibility of organizing sanitary facilities along/near common areas, such as stairways, common flooring storage rooms, etc.

The installation shaft - access from the corridor. There are several common schemes (Fig. 3) for providing a space for integrated MEP systems. These are vertical ducts which can be accessed from the stairwell space or corridors for intervention without disturbing the apartments tenants. Based on the given schemes, advantages and disadvantages of such a solution for installation ducts can be considered. The shafts for the vertical lines of the MEP systems are carried through the entire height of the building and provide space for most installation verticals and measuring instruments (Fig. 4). This solution is followed by a different way of distributing horizontal branches on floors, which is not always feasible due to the distance from the vertical duct, so for some installations it may be a limiting factor. [3]
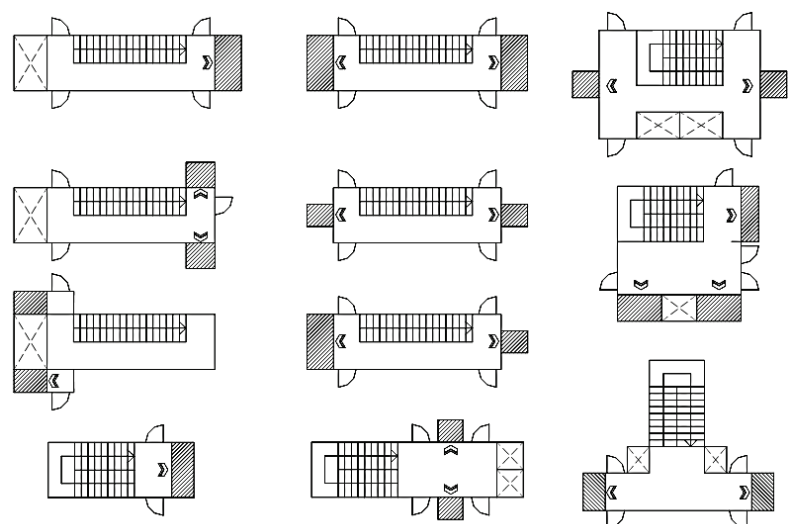

Figure 3 Scheme of possible spaces for integrated MEP system

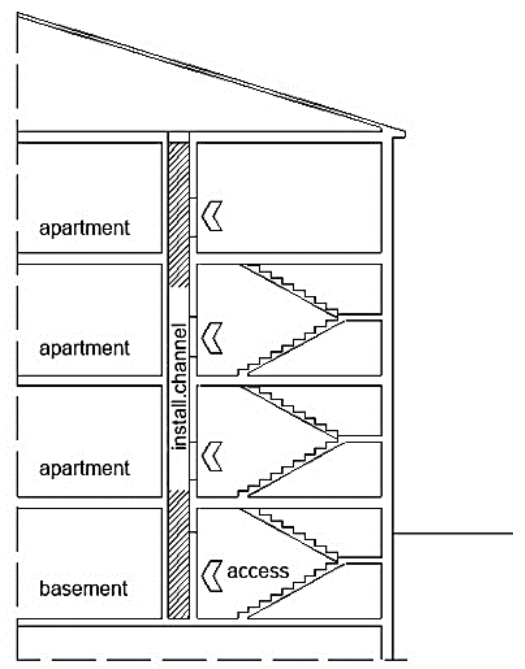

Figure 4 Vertical installation shaft with staircase access 
Skylights and vertical shafts. For apartment buildings where it is impossible to provide access to all installations from common areas, or where such a solution would impair the function and influence the costeffectiveness of the network, consideration may be given to the possibility of introducing vertical shafts of minimal dimensions at points of building dilatation, using climbers to access installations on each floor (by an authorized person) with a controlled entrance from the ground floor or basement (Fig. 5).
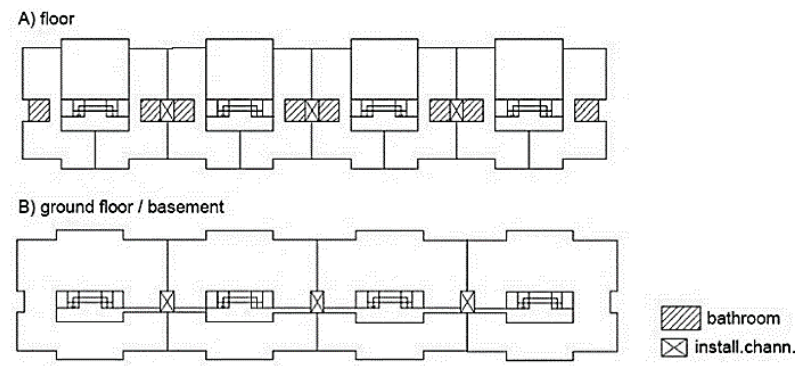

Figure 5 Scheme of the position of the installation shaft with access from ground (B) and floor (A)

Atria or skylights can be used to access installations. In addition, they provide more opportunities for organizing space, as well as natural ventilation and lighting for the side rooms (Fig. 6).

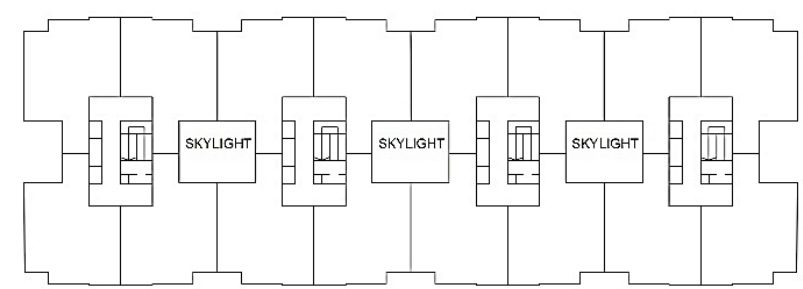

Figure 6 Installations access from the skylight area

Installation rooms on upper floors. In some countries, rooms on upper floors are often designed in stairwells for accommodating measuring instruments (egg France). Rooms are divided according to installations, Ameters of gas consumption; B-water meters; C-electricity meters; D-skylight; E-vertical pipes for gas; L-ventilation; K-valves (Fig. 7) [14].

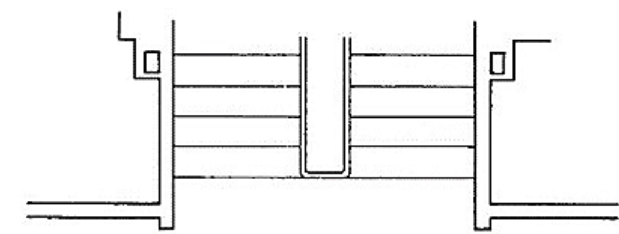

apartment apartment

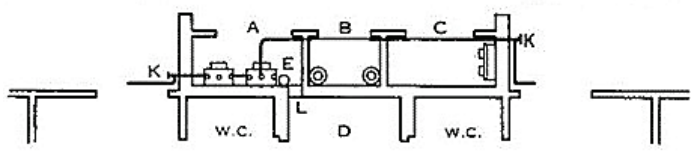

Figure 7 Space on the staircase for installations

Rooms in the basement. In buildings with a basement, a room or several rooms should be planned to enable access to installations (valves, manifolds, measuring devices, etc.) and in buildings without a basement, appropriate access to installations should be provided on the ground floor. In some countries (e.g. Germany) the design of such rooms, in which the installations are grouped, is common practice (Fig. 8), [15].

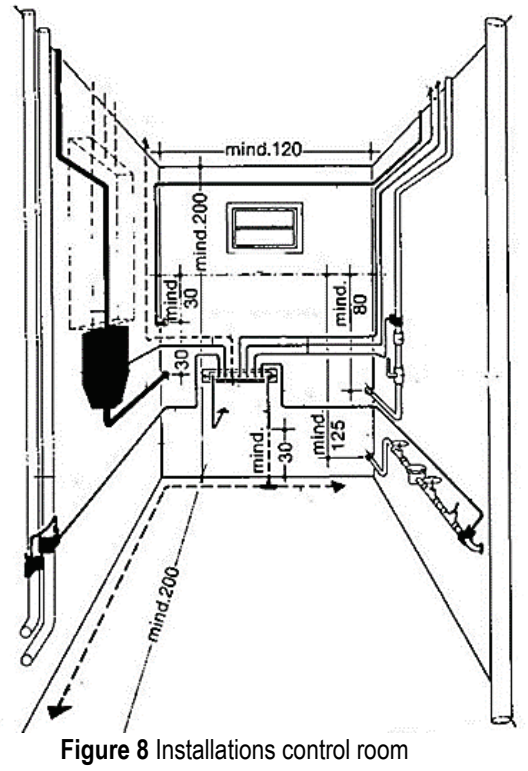

\subsection{Interventions on Existing Buildings 4.2.1 Making Openings from the Stairwell to the Existing Installation Shafts}

The possibilities for enabling access, in particular, water and sewerage installations, by making building adaptations, exist within a large number of residential buildings. Sanitary facilities (or areas in which the installation systems of water supply and sewage are most often installed) of characteristic apartment buildings were analyzed. The following examples represent awarded apartment buildings in Serbian urban settlements which contain over 7000 apartments in total. Here again, it must be noted that because of its inflexibility, the most vulnerable is the sewerage network. Example in Fig. 9 shows the layout of an apartment building with four apartments on the floor. The sanitary facilities are grouped in a way as to border with the stairwell, from which access could be provided to the installation duct.

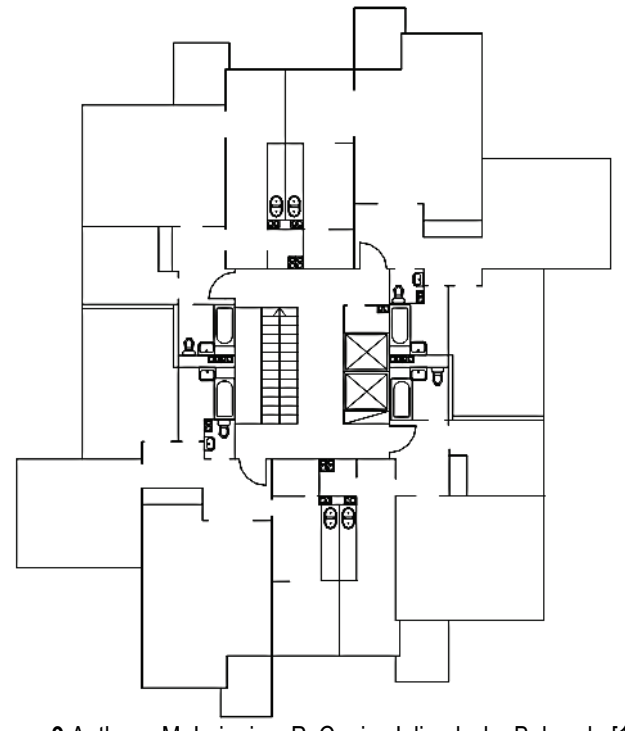

Figure 9 Authors: M. Lojanica, P. Cagic, Julino brdo, Belgrade [16] 
An example of an apartment building in New Belgrade (Fig. 10) shows the functional organization of space where, similar to the previous example, bathrooms are just near the stairwell, while the kitchen is oriented towards the skylight, where it is possible to provide easy access to the kitchen installations.

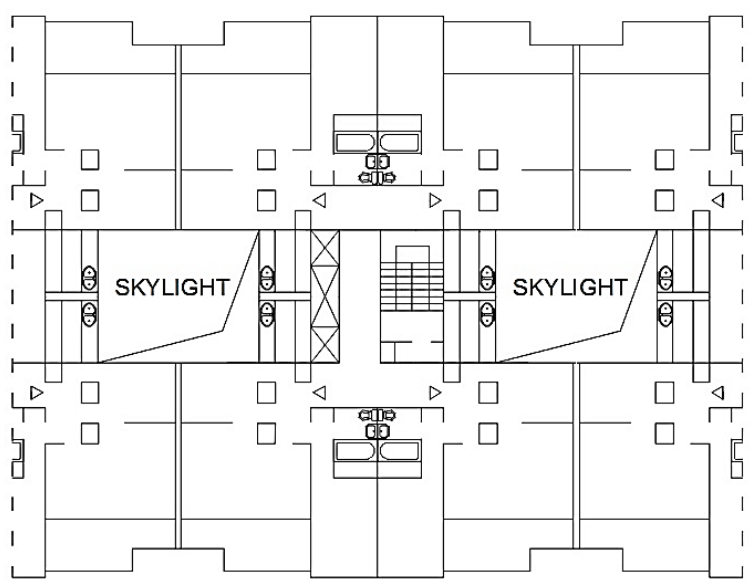

Figure 10 Authors: D. Marusic, Blok 61, 62, N. Belgrade [15]

On the example of an apartment building in the settlement Banjica in Belgrade (Fig. 11), which consists of over 4500 apartments [10] the layout of sanitary facilities is such that the toilets and kitchens are near the stairwell wall, but the bathrooms are next to the façade walls. In such solutions it is possible to provide access to the installation duct of the bathroom on the outside of the building, certainly with absolute appreciation of the aesthetic values of the facade. Particular attention should be given to the execution of works by which new openings on façade walls are made, in terms of insulation and finishing.

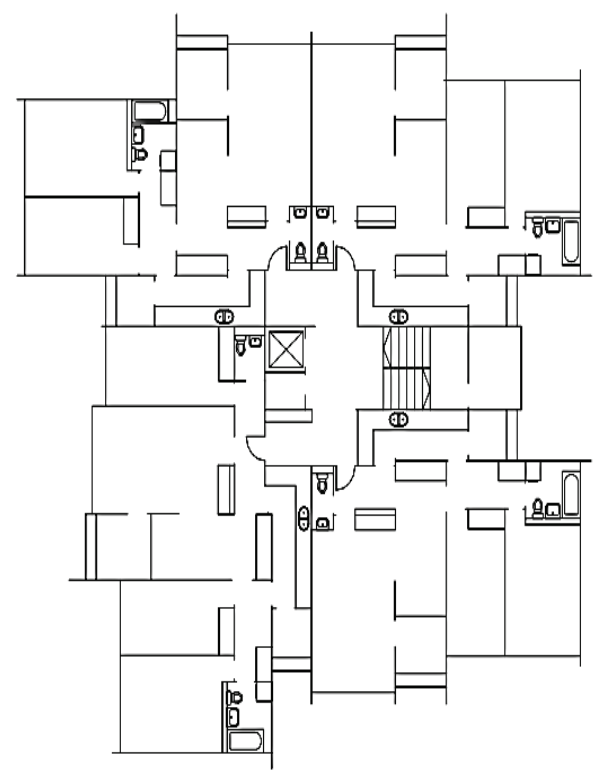

Figure 11 Authors: Drinjaković, Karadzic, Stjepanovic, Banjica, Belgrade [17]

Residential towers with four apartments on each floor (Fig. 12), in addition to the already available installation channels along the bathroom walls, have a vertical installation duct between the toilet and the kitchen. In this case, the installation wells for each apartment were separated, allowing the installations that are located in them to belong to that apartment, which facilitates control and access, although no access is enabled from the space outside the apartment.

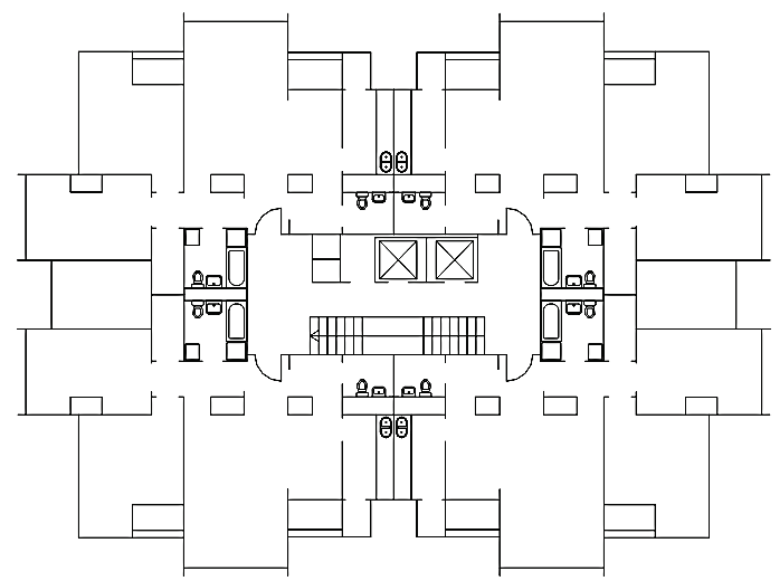

Figure 12 Authors: I. Mlađenović, Bul. 23. oktobra, Novi Sad [14]

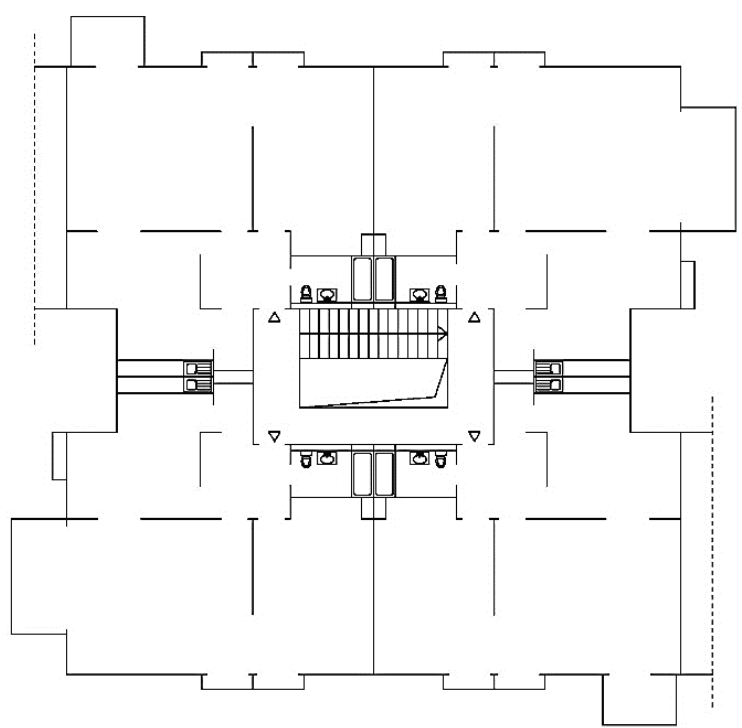

Figure 13 Authors: Djokic, Canak, Settlement Kijevo Knjazevac, Belgrade [8]

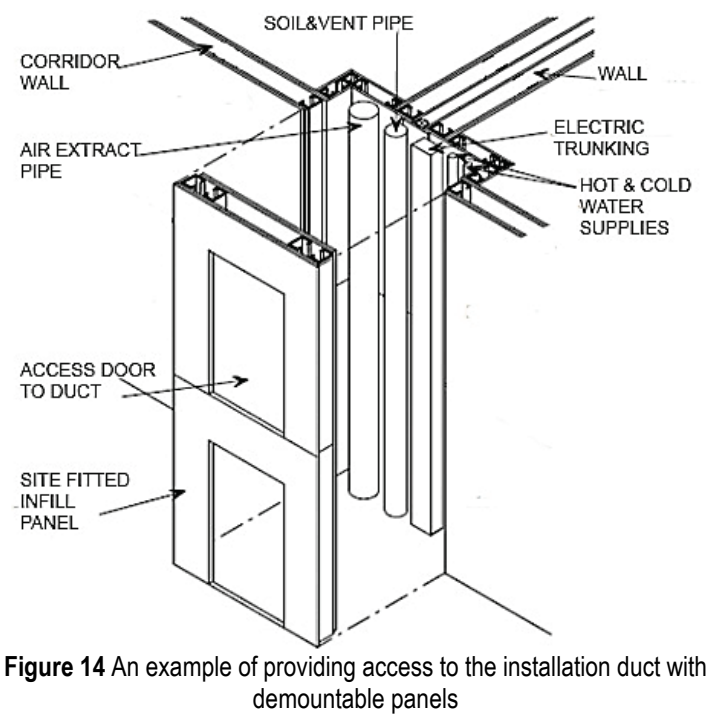

The ground floor of a residential building in the settlement Kijevo Knjazevac in Belgrade (consisting of about 5000 apartments) shows a solution in which sanitary facilities, as well as channels for kitchen installations, are 
completely along the stairwell walls, from which access can be provided to the installation duct. (Fig. 13)

By making openings on existing installation wells from common areas and installing demountable panels it is possible to provide controlled access to MEP system. [18] In this way, a one-time structural intervention and investment solution address a long-term access problem. This way subsequent interventions on installations are enabled by disassembly of the panel by an authorized person (Fig. 14).

\subsubsection{Apartment Renovations}

Adjustment of installation spaces in order to provide easier access, requires significant financial resources and engagement even for small interventions. In addition, practice shows that the owners of apartments and tenants become aware of this problem only when there are failures in the installations or their use encounters difficulty. The age of the housing stock in Serbia is one of the reasons why owners increasingly renovate their apartments. Doing so, they usually renovate sanitary facilities and installations in apartments. This becomes an opportunity to execute certain interventions that will facilitate access to installations. Usually, the investment in renovation requires significant funds to allow easier access to MEP systems by introducing openings towards the existing installation ducts. There are a number of prefabricated elements on the market, such as panels for access through tiled wall surfaces, which can be built into the wall in a way that does not degrade space, which is safe for users, and provides an acceptable solution for accessing installations. [19]

Revision openings. When it comes to inspection shafts and fittings inside the building, they are generally set at the lowest levels on vertical or horizontal branches that are usually visible on the ceiling of the basement. This, of course, is justified in terms of preserving the quality of rooms used for people's stay. In some countries (e.g. the USA), in the lowest floors of the building, instead of manholes, special elements for revision are placed, not only on the vertical, but also on the lower branches. In this way, easy access for inspection is provided. (Fig. 15)

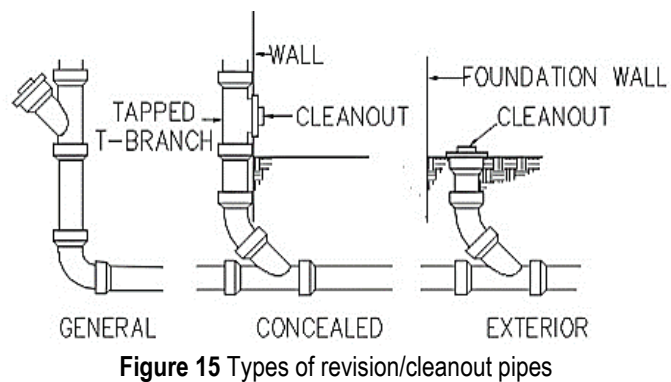

\section{REGULATIONS}

Apartment buildings represent a very specific category, due to their complex function, junction of different MEP system, and because of the split ownership over different parts of the building. Therefore, it is necessary that the use and maintenance are fully regulated in all their aspects. In that sense, it would be important to allocate multi-storey apartment buildings in a separate set of laws and regulations, regarding the entire life cycle of the building, from design, through construction to use or maintenance. It is important, especially for the design phase, to carry out an analysis of the existing regulations and harmonize them with complex ownership relations, architectural design and constructive requirements and technical conditions prescribed by utility services. For newly designed, future buildings, of great importance is precisely defined legal framework for the use and maintenance of MEP system and shared property through a number of housing laws, and, in particular, through contracts for the purchase of an apartment. In these legal documents there should not be the slightest dilemma about what belongs to whom and who is responsible for the functioning of that part of the building. It is necessary, at the earliest stage of planning, through the design, to seek out, harmonize and propose the best solutions that would make the process of exploitation of the object simpler, more efficient and more cost effective for the user and/or the owner of the building. [20] With this regard, a good solution would be a legal obligation to develop a Maintenance Project as an integral part of the Main Design Project. This legally regulated obligation would ensure that each new building, as well as a building that has been in operation for a long period of time, has its own Maintenance Project which, during exploitation, would be subject to possible changes and modifications in the procedures related to the change of equipment and MEP system, possible extensions, renovation, partial or complete change of purpose, etc. [21]

Accordingly, special attention should be paid to the regulations relating to the existing apartment buildings.

The fact is that there is a large number of multi-storey apartment buildings in which it is impossible to alter the existing state of matter and not much intervention in architectural terms is possible.

The regulations must include works on investment maintenance, where the rules on how to perform interventions on certain parts of the building provide precise instructions for better and easier maintenance in the future. The existing Rulebook only defines the time interval when it is necessary to control the shared installations in an apartment building [22], without any overview and regulations on the procedure itself. Also, e.g., according to the Law, the replacement of the floor and wall coverings belongs to current maintenance and does not require a permit, while for the replacement of parts of the MEP system it is necessary to report the works to the competent authorities [23]. This leads to the situation that is completely unsupervised regarding the interventions on the MEP system performed inside the apartment units. It is often the case that works are carried out by persons without appropriate qualifications and licenses. Due to the relatively underdeveloped (or irregularly developed) real estate market, the majority of apartment owners do not think in a "market" way, nor do they see themselves as an active participants in the process of maintaining residential buildings owned by them. One of the tasks in solving this problem would be education of apartment owners, who in most cases are completely unaware of what constitutes their legal obligation when it comes to maintaining apartment buildings. In addition, most of the legal obligations in this area are viewed as a kind of government 
incentive, not as an investment in the property and preservation of its value.

\section{CONCLUSION}

This paper analyzes the possibilities of providing access to MEP systems in apartment buildings in order to ensure their adequate maintenance. Considering the property transformation that was carried out in Serbia in the last decades of the $20^{\text {th }}$ century, there was a major problem in maintaining building installations, since the owners of apartments then acquired the legal obligation to maintain common parts of the building. For this reason, the research considers the importance of the spatial organization of the MEP systems, as well as the legal framework for the use and maintenance of installations as common parts of the building.

Private ownership of an individual apartment or unit in multi-storey buildings assumes shared rights and obligations related to common elements and parts of the building, which includes MEP systems as extremely important. The largest percentage of the housing stock in Serbia and other countries of former Yugoslavia (e.g. Croatia, Bosnia) was built in the period from 1946 to 1990 , when, due to low cost solutions, the design of MEP systems was done considering the building as the basic unit, not the apartment.

Based on the performed research and analysis, it can be found that the largest problems are in the area of water supply and sewerage, the design of which is the obligation of the architects. They must be more interested in solving this problem in order to prevent other negative consequences on buildings such as aesthetic and physical demolitions. The spheres of possible solutions are within the design phase for new buildings, interventions on existing buildings and amendments to regulations in this field. MEP systems and devices require high investment costs, and if maintenance of these networks is in the domain of apartment owners, it is necessary that the law precisely defines the obligation to provide access to the actual installation. This can be achieved only with an active participation of architects in the adoption of legislation related to this topic important from the preliminary concept phase of design.

Measures and recommendations for possible solutions to be applied at the design stage are:

1. Timely harmonization of architectural design with installation design of sewage and water supply and structure. The organization of space can significantly influence the grouping of installations in the installation shafts or walls, and especially the position of sanitary facilities along the walls of common areas of the building: stairways, shared storage rooms, etc.

2. In the early stages of the design process, the architect should consider the possible positions of installation wells shown in Fig. 3, in order to provide unhindered access to the installations by the owners of apartments or authorized persons.

3. Existence of skylights in the building gives possibility for access to installations on each floor.

4. Providing room for control instruments and installation devices on each floor, as well as in the basement.
By examining examples of successfully completed apartment buildings, it can be stated that, with minimal adjustments and interventions in the design of the apartment, a significant contribution of the architects to solving this problem can be achieved without disturbing the function and quality of the living space.

By analyzing the examples of existing multi-storey apartment buildings, the following was found:

- $\quad$ sanitary facilities in most of the apartment buildings are mainly designed to border with common premises in the building (corridors, communications), which greatly facilitates access to the MEP systems

- the examples show that the position of sanitary facilities, i.e. installations, does not, in any way, impair the functionality and spatial organization of the apartment

- for the analyzed apartment buildings, the shafts for the vertical lines of the MEP systems are carried out over the entire height of the building and provide space for most installation verticals and measuring instruments

- the shown solutions are not always feasible, since the distance from the vertical duct influences the horizontal networking scheme on the floors, and this may be a limiting factor for some installations.

Given that the financial indicators of investments in the housing fund in developed countries show that funds invested in the maintenance of existing buildings are increasingly exceeding the funds invested in the development of new buildings [24], it is clear that this problem requires the activation of corrective mechanisms in the professional domain, as well as in the system as a whole.

In this sense, the underdeveloped regulation and its application, is first to address. New ownership requires additional or more precise regulations, both for new buildings and for the existing ones. Maintenance management refers to an understanding of the maintenance process, which includes the activities that are planned and carried out to maintain, repair, and alter building properties according to the requirements of owners, users and community, [25].

\section{REFERENCES}

[1] Au-Yong, C. P., Shah Ali, A., \& Ahmad, F. (2013). Office Building Maintenance: Cost Prediction Model. Građevinar, 65(9), 803-809. https://doi.org/10.14256/JCE.677.2012

[2] Horner, R. M. W., El-Haram, M. A., \& Munns, A. K. (1997). Building maintenance strategy: a new management approach. Journal of Quality in Maintenance Engineering, 3(4), 273-280. https://doi.org/10.1108/13552519710176881

[3] Lee, S. \& Ahn, Y. (2018). Analyzing the Long-Term Service Life of MEP Using the Probabilistic Approach in Residential Buildings. Sustainability, 10(10), 3803. https://doi.org/10.3390/su10103803

[4] Jurenić, T. (2001). Analiza instalacionih mreža u kolektivnim stambenim zgradama sa aspekta izmenjenih vlasničkih odnosa, master thesis, Univerzitet u Beogradu, Arhitektonski fakultet, Beograd. (in Serbian)

[5] Grum, B. (2017). Impact of facilities maintenance on user satisfaction. Facilities, 35(7/8). https://doi.org/10.1108/F-03-2016-0034

[6] Country Profiles on the Housing Sector: Serbia and Montenegro. Economic Commission for Europe Geneva, United Nations, New York and Geneva, 2006. 
http://www.unece.org/fileadmin/DAM/hlm/prgm/cph/count ries/serbia\%20and\%20montenegro/CP\%20Serbia\%20\&Mo ntenegroPub.pdf

[7] Bežovan, G. (2014). Standard stanovanja i izazovi razvoja stambene politike u Hrvatskoj, Devetnaesti forum poslovanja nekretninama, Hrvatska gospodarska komora sektor za trgovinu, 77-94. http://www.agenti.hr/sadrzaj/infoagent/strukovni-forumi/forum-19/19-forum-Standardstanovanja-izazovi-razvoja-stambene-politike.pdf (in Croatian)

[8] Istorijat planiranja u $\mathrm{BiH}$ - 70 godina postojanja, Federalni zavod za programiranje razvoja, Sarajevo, januar 2016. file:///C:/Users/korisnik/Downloads/Monografija\%20Zavod a.pdf

[9] Srpski standard: Izračunavanje površina i zapremina objekata u oblasti visokogradnje- koeficijenti za obračun (Calculation of area indicators of buildings), Sl. list RS br. 32/02, Beograd 2002. (in Serbian)

[10] Carretero-Ayuso, M. J., Moreno-Cansado, A., \& GarcíaSanz-Calcedo, J. (2017). An analysis of technical facilities failures in modern Spanish houses. Building Serv. Eng. Res. Technol., 38(4) 490-498. https://doi.org/10.1177/0143624417701802

[11] (1975). Arhitektura i urbanizam 74-77, Časopis Saveza inženjera i tehničara Jugoslavije, Beograd. (in Serbian)

[12] Uslovi i tehnički normativi za projektovanje stambenih zgrada i stanova (Terms and technical norms for the design of residential buildings and apartments), Sl. glasnik grada Beograda broj 32/IV, 1983. (in Serbian)

[13] Pravilnik o tehničkim propisima i merama za izvođenje radova na gradskoj kanalizaciji, kanalizacionim uređajima i kućnim instalacijama (Rulebook on technical regulations and measures for the works on city sewerage and home installations), Zbirka tehničkih propisa u građevinarstvu 2, Građevinska knjiga, Beograd, 1980. (in Serbian)

[14] Charlent, H. (1980). Traité Pratique de Plomberie et d'instalation sanitaire. Edité par Garnier, Paris. (in French)

[15] RWE - Bau - Handbuch Tehnicher Ausbau 1979/80, RWE, Essen, 1980.

[16] Knežević, G. (1989). Višestambene zgrade. Tehnička knjiga, Zagreb. (in Croatian)

[17] Stan i stanovanje, Časopis Izgradnja - posebno izdanje (Apartment and habitation, Journal Construction - special edition), Beograd, 1972. (in Serbian)

[18] https://www.steelconstruction.info/Modular_construction

[19] https://www.howegreen.us/accesscovers/wall/

[20] Radojević, M., Miholčić, J., \& Jurenić, T. Facility Management - Monitoring Energy Consumption in Buildings for Education, Međunarodni naučno-stručni simpozijum.

[21] Jurenić, T. \& Radojević, M. (2012). Održavanje kolektivnih stambenih zgrada kao proces - instalacione mreže, Zbornik radova: Planiranje, projektovanje, građenje i obnova graditeljstva INDIS 2012, Fakultet tehničkih nauka Univerziteta u Novom Sadu, Novi Sad, 370-376. (in Serbian)

[22] Pravilnik o vrsti, obimu i dinamici aktivnosti tekućeg i investicionog održavanja zgrada i načinu sačinjavanja programa održavanja (Rulebook of activities for maintenance of buildings and method of making the maintenance program), Sl. glasnik RS, br. 54/17, Beograd, 2017. (in Serbian)

[23] Zakon o planiranju i izgradnji (The Law on Planning and Construction), Sl. glasnik RS, br. 132/14 i 145/14, Beograd, 2014. (in Serbian)

[24] Cerić, A. \& Katavić, M. (2000). Upravljanje održavanjem zgrada. Građevinar, 53(2), 83-89.

[25] Barbarosoglu, B. V. (2018). Early Detection of Maintainability Issues in MEP Systems Using BIM, Illinois Institute of Technology, ProQuest Dissertations Publishing, 10792391. https://doi.org/10.1007/978-3-030-00220-6_40

\section{Contact information:}

Tatjana JURENIĆ, PhD, Assist. Professor

(Corresponding author)

University of Belgrade,

Faculty of Architecture,

Bul. kralja Aleksandra 73/II, 11000 Belgrade, Serbia

E-mail: tanja@arh.bg.ac.rs

\section{Miloš Gašić, PhD}

University of Belgrade,

Faculty of Architecture,

Bul. kralja Aleksandra 73/II, 11000 Belgrade, Serbia

Aleksandra ČABARKAPA, PhD

University of Belgrade,

Faculty of Architecture,

Bul. kralja Aleksandra 73/II, 11000 Belgrade, Serbia 